\title{
The phagocytosis of mycoplasmas
}

\author{
A. J. MARSHALL, R. J. MILES and L. RICHARDS* \\ Division of Life Sciences, King's College London, Campden Hill Road, London W8 7AH
}

\section{Introduction}

Mycoplasmas are recognised primarily as extracellular parasites or pathogens of mucosal surfaces, although recent evidence suggests that certain species may invade host cells. ${ }^{1-5}$ The role of mycoplasmas in disease is also being reassessed in the light of recent findings linking them with other infectious agents, including $\mathrm{HIV},{ }^{1,2,5-9}$ meningococci ${ }^{10,11}$ and chlamydiae. ${ }^{12.13}$

Phagocytic cells, such as macrophages and polymorphonuclear leucocytes (PMNL), comprise the first line of defence against mycoplasmas invading the lung and genitourinary tract. ${ }^{14}$ Cells of the macrophagemonocyte lineage patrol the respiratory and genitourinary mucosae, accumulating at sites of mycoplasma infection. ${ }^{15}$ Not only do they carry out effector functions such as receptor-mediated phagocytosis, ${ }^{15,16}$ but they are also important accessory cells of the immune system involved in antigen presentation and the production of cytokines. ${ }^{17}$ After an inflammatory stimulus, PMNL (together with peripheral blood monocytes) are also recruited to the area by chemotaxis $^{18}$ and large numbers amass in respiratory, synovial and cartilaginous tissues infected with mycoplasmas. ${ }^{19,20}$ Thus, at the onset of infection, these two cell types are the main mediators of immunity to mycoplasmas; indeed, the outcome of this interaction may determine the subsequent progression of disease.

Over the past 25 years, many of the reports concerning the interaction of mycoplasmas with phagocytes have appeared contradictory, and the mechanisms by which pathogenic mycoplasmas circumvent innate immune responses and go on to establish disease remain poorly understood. In this review, we summarise current knowledge concerning the phagocytosis of mycoplasmas, emphasising recent advances and highlighting areas where knowledge is incomplete, in an attempt to clarify the way forward for future studies. More comprehensive reviews detailing early studies can be found elsewhere. ${ }^{15,17,21}$

Received 31 March 1994; revised version accepted 1 March 1995.

* Correspondence to be addressed to Dr. Richards.

\section{Interaction between phagocytes and mycoplasmas in vivo}

\section{Innate responses to mycoplasma infection}

Many reports describe the interaction of macrophages or PMNL, or both, with mycoplasmas in vivo. ${ }^{22-39}$ Much of the work has centred on the effects of Mycoplasma pulmonis, a mouse pathogen, on the cellular responses of mice and rats. In the early 1970s, Cassell et al. ${ }^{18,22}$ studied the clearance of $M$. pulmonis from the lower respiratory tract of Fischer rats and CD-1 strain mice. They found that rats were able to clear this mycoplasma from the lung relatively efficiently, with only limited infiltration of PMNL, and deduced that the organisms were taken up rapidly by alveolar macrophages. Mice, on the other hand, cleared mycoplasmas much more slowly and no association between mycoplasma antigen and macrophages was observed. Moreover, the accumulation of PMNL in the bronchi of infected mice was massive and much of the tissue destruction observed was attributed to PMNL hydrolytic activity. ${ }^{18}$ Lindsey and Cassell $^{19}$ have also used immunofluorescence techniques to show the association of $M$. pulmonis antigen with PMNL in the alveoli of infected mice. Similar prominent alveolar infiltrations of macrophages and PMNL have been observed in mice injected with live, killed or membrane preparations of $M$. pulmonis, suggesting that mycoplasma antigen alone may be sufficient to attract phagocytes to foci of infection and to stimulate inflammatory responses. ${ }^{22,30}$ Recently, Ross et $a l^{40}$ have demonstrated that $M$. pulmonis membrane preparations possess a potent chemoattractant activity for peritoneal and alveolar macrophages from fresh rat serum. This is corroborated by Meier et al. ${ }^{33}$ who showed increased PMNL aggregation and activation (as measured by respiratory burst activity) in polyarthritic joint fluid from $M$. arthritidis-infected SPF-Lewis rats, and Komatsu, ${ }^{34}$ who showed degranulation and specific chemotaxis of eosinophils towards $M$. pneumoniae in the lungs of guinea-pigs. In another study, Taylor and Taylor-Robinson ${ }^{23}$ observed increased proliferation and dissemination of $M$. pulmonis and $M$. pneumoniae in $\mathrm{T}$ cell-depleted hamsters and mice, but a decreased 
severity of disease (as measured by lesion score) when compared with control animals. This was attributed to the reduced accumulation of macrophages and PMNL, which were less activated and showed a reduced capacity to kill mycoplasmas and to induce inflammatory responses.

Many mycoplasma syndromes are characterised by the persistence of antigen in the lung parenchyma before the onset of antibody production, despite the presence of phagocytes. For example, $M$. bovis antigen has been shown to persist in the lung parenchyma of gnotobiotic calves for at least 4 weeks after infection, ${ }^{29}$ and $M$. pulmonis strains have been shown to survive in the respiratory tract of mice, despite the accumulation of peritoneal macrophages. ${ }^{26,27}$

More recently, Trichopoulos and colleagues ${ }^{41,42}$ have investigated the effect of $M$. arthritidis on the phagocytic activity of macrophages of rats and mice. By studying the kinetics of colloidal carbon clearance in the lungs, they have shown that phagocytic activity is significantly depressed $12 \mathrm{~h}$ post-infection, returns to normal at $24 \mathrm{~h}$, then increases significantly by 7 days, and subsequently returns to control levels by the end of the fourth week. ${ }^{42}$ They suggest that the early depressive effect on phagocytic activity may be related to superantigen activity, with the production of suppressive cytokines, such as macrophage-de-activating factor. The later expansion of the macrophage population might result from the stimulation of autoreactive clones of $\mathrm{T}$ and $\mathrm{B}$ lymphocytes. Presumably, increased macrophage activity may also be a factor in the development of the chronic arthritis found in mycoplasma-infected mice.

\section{Factors that affect innate responses}

The killing and clearance of $M$. pulmonis from the respiratory tract, in the absence of specific antibody, depend on the strain of mycoplasma, ${ }^{31}$ mouse $^{28}$ or rat $^{32}$ studied; thus, differences in disease severity from host to host may relate to the effectiveness of nonspecific phagocytic mechanisms in eliminating particular mycoplasma strains. ${ }^{31}$ Recently Lai et al. ${ }^{43}$ studied the genetic control of resistance to $M$. pulmonis infection in mice, demonstrating that macrophages harvested from infected $\mathrm{H}-2 \mathrm{~b}(\mathrm{C} 57 \mathrm{BL} / 6)$ mice are much more effective at killing mycoplasmas than macrophages from infected CT (T2) mice. Activation of macrophage bactericidal function may help to explain genetic variation in resistance to $M$. pulmonis infection.

Different types of phagocytic cell also exhibit varying mycoplasmacidal activity. The clearance of $M$. pulmonis from the peritoneal cavity of SPF/CBA mice is enhanced by the presence of increasing numbers of peritoneal macrophages, but not PMNL. ${ }^{16}$ Brownlie et $a .^{25}$ demonstrated that PMNL-rich exudates, induced in the bovine mammary gland after challenge with $M$. dispar or ureaplasmas, were ineffective at eliminating these organisms, and suggested that neutropenia following infection may facilitate mycoplasma growth and aggravate mastitis. Interestingly, an elevation in the number of mature and immature PMNL is found in the respiratory tract of neonates colonised with Ureaplasma urealyticum. ${ }^{44}$

Natural killer (NK) cells may be the principal cells responsible for mycoplasmacidal activity in the respiratory tract of mice, ${ }^{31}$ a view supported by studies on mice with severe combined immunodeficiency ${ }^{45}$ and BALB $/ \mathrm{c}^{46-48}$ mice, infected with $M$. pulmonis; clearance of mycoplasmas is inhibited significantly by antibodies to interferon (IFN)- $\gamma$ or NK cells. The mycoplasmacidal activity of NK cells is attributed mainly to their ability to produce IFN- $\gamma$, which activates macrophage bactericidal mechanisms.

Environmental factors, such as nitrogen dioxide $\left(\mathrm{NO}_{2}\right)$, may suppress non-specific immunity to mycoplasma infection and increase disease severity. ${ }^{39.49}$ Exposure to $\mathrm{NO}_{2}$ at doses $>5 \mathrm{ppm}$ decreases intrapulmonary killing and exacerbates disease. Davis et al. ${ }^{39}$ have shown that this effect results largely from $\mathrm{NO}_{2}$-mediated damage to alveolar macrophages, leading to decreased viability and impaired bactericidal capability.

\section{What do in-vivo studies tell us?}

Clearly the outcome of the initial mycoplasmaphagocyte interaction plays an important role in determining the progression of infection and the severity of disease. Several factors appear to determine the capacity of a host to eliminate mycoplasmas by phagocytosis. First, phagocyte activation, induced by mycoplasma either directly or via cytokine production, is important in determining mycoplasmacidal activity. Second, the efficiency of phagocytosis varies with both the strain of mycoplasma and the individual host. Third, the nature and origin of a phagocyte influence its capacity to engulf and destroy mycoplasmas, probably as a result of differences in surface receptors or bactericidal mechanisms. Finally, environmental factors may modulate the innate immune system resulting in impaired phagocytic responses.

\section{Interaction between phagocytes and mycoplasmas in vitro}

\section{The importance of opsonisation}

Three basic types of interaction between phagocytes and mycoplasmas have been studied in vitro; phagocytosis of unopsonised mycoplasmas, phagocytosis of mycoplasmas exposed to non-specific serum opsonins (e.g., complement), and phagocytosis of mycoplasmas exposed to specific serum opsonins (e.g., IgG or IgA). Most mycoplasmas resist phagocytosis in the absence of opsonins (table). The capacity of phagocytes to recognise unopsonised bacterial surfaces is dependent on electrostatic charge, van der Waals attraction and hydrophobicity. In our view, the 
Table. In-vitro studies of the interaction between mycoplasmas and phagocytic cells

\begin{tabular}{|c|c|c|c|c|c|}
\hline \multirow{2}{*}{$\begin{array}{l}\text { Mycoplasma } \\
\text { species }\end{array}$} & \multirow{2}{*}{$\begin{array}{l}\text { Phagocyte* } \\
\text { type/source }\end{array}$} & \multicolumn{3}{|c|}{ Phagocytosis in opsonisation conditions $\dagger$} & \multirow{2}{*}{$\begin{array}{l}\text { Reference } \\
\text { no. }\end{array}$} \\
\hline & & unopsonised & $\begin{array}{l}\text { non-specifically } \\
\text { opsonised } \ddagger\end{array}$ & $\begin{array}{l}\text { specifically } \\
\text { opsonised } \ddagger\end{array}$ & \\
\hline M. arthritidis & $\begin{array}{l}\text { Human/rabbit PMNL } \\
\text { Mouse peritoneal } \mathrm{M} \phi \\
\text { Rabbit peritoneal } \mathbf{M} \phi\end{array}$ & $\begin{array}{l} \pm \\
- \\
-\end{array}$ & $\begin{array}{c}\mathrm{ND} \\
-[\mathrm{M}][\mathrm{GP}] \\
-[\mathrm{M}]-[\mathrm{R}]\end{array}$ & $\begin{array}{l}+[\mathrm{R}] \\
+[\mathrm{R}] \\
-[\mathrm{M}]\end{array}$ & $\begin{array}{l}52 \\
53 \\
53\end{array}$ \\
\hline M. bovis & $\begin{array}{l}\text { Bovine PMNL } \\
\text { Bovine PMNL } \\
\text { Bovine M } \phi \\
\text { Mouse PMNL/M } \phi\end{array}$ & $\begin{array}{l}- \\
- \\
- \\
-\end{array}$ & $\begin{array}{l}\text { ND } \\
-[R] \\
-[R] \\
\text { ND }\end{array}$ & $\begin{array}{c}\text { ND } \\
-[\mathrm{B}] \\
+[\mathrm{B}] \\
+[\mathrm{R}]+[\mathrm{B}]\end{array}$ & $\begin{array}{l}72 \\
54 \\
54 \\
16\end{array}$ \\
\hline M. buccale & Human PMNL & \pm & $\pm[\mathrm{H}]$ & $\pm[R]$ & 50 \\
\hline M. dispar & $\begin{array}{l}\text { Bovine PMNL/M } \phi \\
\text { Bovine PMNL } \\
\text { Mouse PMNL/M } \phi\end{array}$ & $\begin{array}{l}- \\
- \\
-\end{array}$ & $\begin{array}{l}\text { ND } \\
-[R] \\
\text { ND }\end{array}$ & $\begin{array}{l}+[\mathrm{R}]+[\mathrm{B}] \\
-[\mathrm{R}]+[\mathrm{B}] \\
+[\mathrm{R}]+[\mathrm{M}]\end{array}$ & $\begin{array}{l}16 \\
54 \\
27\end{array}$ \\
\hline M. fermentans & Human PMNL & \pm & $\pm[\mathrm{H}]$ & $\pm[R]$ & 50 \\
\hline M. gallisepticum & Human PMNL & + & $+[\mathrm{H}]+[\mathrm{M}]$ & ND & 57 \\
\hline M. hominis & $\begin{array}{l}\text { Human PMNL } \\
\text { Human/rabbit PMNL }\end{array}$ & \pm & $\begin{array}{l} \pm[\mathrm{H}] \\
\pm[\mathrm{H}]\end{array}$ & $\begin{array}{l}+[\mathrm{C}] \\
\pm[\mathrm{R}]\end{array}$ & $\begin{array}{l}51 \\
50,52\end{array}$ \\
\hline M. hyorhinis & Bovine PMNL & + & ND & ND & 77 \\
\hline M. neurolyticum & Human PMNL & + & $+[\mathrm{H}]+[\mathrm{M}]$ & ND & 57,58 \\
\hline M. orale & Human PMNL & \pm & $\pm[\mathrm{H}]$ & $\pm[R]$ & 50 \\
\hline M. pneumoniae & $\begin{array}{l}\text { Human PMNL } \\
\text { Guinea pig alveolar } \\
\text { \& peritoneal } \mathrm{M} \phi \\
\text { Mouse peritoneal } \mathrm{M} \phi \\
\text { P388D1 cell line }\end{array}$ & $\begin{array}{l} \pm \\
+ \\
- \\
- \\
- \\
- \\
-\end{array}$ & $\begin{array}{c} \pm[\mathrm{H}] \\
+[\mathrm{H}]+[\mathrm{M}] \\
\mathrm{ND} \\
-[\mathrm{R}] \\
+[\mathrm{GP}]+[\mathrm{R}] \\
\mathrm{ND} \\
\mathrm{ND}\end{array}$ & $\begin{array}{c}+[\mathrm{C}] \pm[\mathrm{R}] \\
\quad \mathrm{ND} \\
+[\mathrm{R}] \\
\quad \mathrm{ND} \\
+[\mathrm{R}] \\
+[\mathrm{R}] \\
\quad \pm[\mathrm{R}]\end{array}$ & $\begin{array}{l}50,51 \\
57,58 \\
63,65,76 \\
62 \\
56 \\
61 \\
61\end{array}$ \\
\hline M. pulmonis & $\begin{array}{l}\begin{array}{l}\text { Mouse alveolar \& } \\
\text { peritoneal } \mathbf{M} \phi\end{array} \\
\text { Mouse PMNL \& M } \phi\end{array}$ & $\begin{array}{l}- \\
- \\
- \\
-\end{array}$ & $\begin{array}{c}\text { ND } \\
\text { ND } \\
\text { ND } \\
-[R][M]\end{array}$ & $\begin{array}{c}+[\mathrm{R}] \\
+[\mathrm{R}]-[\mathrm{M}] \\
\quad \mathrm{ND} \\
+[\mathrm{R}]+[\mathrm{M}]\end{array}$ & $\begin{array}{l}61,66,67,69 \\
53,71,75 \\
26 \\
27\end{array}$ \\
\hline M. salivarium & $\begin{array}{l}\text { Human PMNL \& Mono } \\
\text { Human PMNL }\end{array}$ & $\begin{array}{l}+ \\
\pm\end{array}$ & $\begin{array}{l}\mathrm{ND} \\
\pm[\mathrm{H}]\end{array}$ & $\begin{array}{l}+[R] \\
+[C]\end{array}$ & $\begin{array}{l}55 \\
51\end{array}$ \\
\hline $\begin{array}{l}\text { Ureaplasma } \\
\text { urealyticum } \\
\text { Acholeplasma } \\
\text { laidlawii }\end{array}$ & $\begin{array}{l}\text { Human PMNL } \\
\text { Bovine PMNL } \\
\text { Mouse peritoneal M } \phi \\
\text { P388D1 cell line }\end{array}$ & $\begin{array}{l} \pm \\
\pm \\
+ \\
+ \\
+\end{array}$ & $\begin{array}{l} \pm[\mathrm{H}] \\
\pm[\mathrm{H}] \\
\mathrm{ND} \\
\mathrm{ND} \\
\mathrm{ND}\end{array}$ & $\begin{array}{l} \pm[\mathrm{R}] \\
+[\mathrm{C}] \\
\mathrm{ND} \\
+[\mathrm{R}] \\
+[\mathrm{R}]\end{array}$ & $\begin{array}{l}50 \\
51 \\
77 \\
61 \\
61\end{array}$ \\
\hline
\end{tabular}

* PMNL, polymorphonuclear leucocyte; $\mathbf{M} \phi$, macrophage; Mono, peripheral blood monocyte.

$\uparrow$ Phagocytosis: + , present; - , absent; \pm , contradictory results (i.e., evidence for phagocytosis/phagocytosis-related phenomena, but an absence of intracellular killing of mycoplasmas by phagocytes); ND, assays not done.

‡ Serum source is indicated: $[\mathrm{R}]$ rabbit; $[\mathrm{GP}]$ guinea-pig; $[\mathrm{B}]$ bovine; $[\mathrm{M}]$ murine; $[\mathrm{C}]$ caprine; $[\mathrm{H}]$ human.

resistance of unopsonised mycoplasmas to phagocytosis is not particularly significant in pathogenesis as many species of bacteria avoid phagocytosis in the absence of opsonins, and unopsonised cells are essentially "artificial" and would rarely if ever be encountered by phagocytes in vivo.

The lack of published data on the interaction of non-specifically opsonised mycoplasmas with phagocytes is surprising as non-immune host defences are a key stage in resistance to infection. Non-specific opsonisation involves the deposition of complement breakdown products ( $\mathrm{C} 3 \mathrm{~b}, \mathrm{C} 3 \mathrm{bi}, \mathrm{C} 3 \mathrm{dg}$ and $\mathrm{C} 4 \mathrm{~b}$ ) on the mycoplasma cell surface, but other opsonins, such as $\mathrm{C}$-reactive protein, fibronectin, $\alpha 2$-macroglobulin, lipoprotein surfactants, tuftsin and non-specific serum proteases may also be involved. For many mycoplasma species, viable count data suggest that non-specific opsonisation has little beneficial effect on phagocyte bactericidal activity, ${ }^{27,50-54}$ whereas studies with electronmicroscopy (EM), chemiluminescence (CL) and ${ }^{14} \mathrm{CO}_{2}$ production demonstrate increased phagocytosis and respiratory burst activity when mycoplasmas are treated with non-specific opsonins. ${ }^{50-52,55-58}$ This may reflect phagocytosis of mycoplasmas which retain their viability. Surprisingly, little work has been performed on the phagocytosis of non-specifically opsonised cells of $M$. pneumoniae, the main mycoplasma pathogen in man (table). For pathogens such as $M$. hominis ${ }^{51,52,59}$ and $M$. fermentans strain incognitus, ${ }^{59}$ data indicate survival following phagocytosis in the presence of non-specific opsonins; however, such mycoplasmas may be exceptional. ${ }^{60}$

Most in-vitro studies have concentrated on specifically opsonised mycoplasmas (table). Opsonisation with specific antibody, either with or without complement is followed usually by rapid phagocytosis and 
intracellular killing, ${ }^{16,27,50,51,61-65}$ although not always. $^{\tilde{5} 0,52-54}$ The increased efficiency of phagocytic uptake and killing results from the specific recognition of the Fc portion of mycoplasma-bound IgG or IgA by receptors on the phagocyte surface. Provided that it is of the right idiotype-isotype, antibody can act as an effective opsonin and agglutinin as well as directly neutralising mycoplasmas. Those cases in which antibodies have been ineffective in promoting phagocytosis probably reflect the fact that they were inappropriate or non-opsonic.

\section{In-vitro methods for studying the mycoplasma- phagocyte interaction}

Several approaches have been adopted in the search for a reliable in-vitro assay to assess the rate and extent of mycoplasma ingestion and killing by phagocytes, these include phase-contrast microscopy, ${ }^{56,62,66,67}$ electronmicroscopy (EM) $)^{51,55,57,58,61-63,66,68-70}$ autoradiography, ${ }^{62.66}$ uptake of radiolabelled mycoplasmas, ${ }^{63,66}$ inhibition of ${ }^{3} \mathrm{H}$-uridine uptake by macrophages, ${ }^{61}$ stimulation of $1-\left[{ }^{14} \mathrm{C}\right]$-glucose metabolism by phagocytes, ${ }^{52,71}$ immunofluorescence staining and flow cytometry, ${ }^{72,73}$ spectrophotometry, ${ }^{69,73}$ trypan blue exclusion, ${ }^{74}$ enzyme-linked immunosorbent assay (ELISA), ${ }^{63}$ titration of viable organisms, ${ }^{16,26,27,50-55,66,75,76}$ and luminol-dependent chemiluminescence (CL). ${ }^{50,51,72,77-79}$

Techniques such as microscopy, autoradiography, uptake of radiolabelled organisms, immunofluorescence and ELISA assess the topological relationship between mycoplasmas and phagocytes. Others, such as inhibition of ${ }^{3} \mathrm{H}$-uridine uptake, $\left[{ }^{14} \mathrm{C}\right]$-glucose breakdown, spectrophotometric measurement of enzyme activity and luminol-dependent CL, analyse the metabolic response of phagocytes to mycoplasmas. Phagocyte viability can be measured by trypan blue exclusion assays, whereas viable counts determine extracellular and intracellular survival of mycoplasma.

\section{Technical difficulties}

In-vitro studies of the phagocytosis of mycoplasmas are hampered by factors such as bacterial aggregation, ${ }^{55,75}$ the tendency of mycoplasmas to adhere spontaneously to phagocytes, ${ }^{61}$ the lack of distinguishing morphological or staining properties for mycoplasmas, ${ }^{61}$ the difficulty in differentiation of cell-adherent and ingested organisms, ${ }^{50}$ mycoplasma susceptibility to $\operatorname{lysis}^{61}$ and discrepancies between bacterial cells grown in vitro or in vivo. ${ }^{26}$

Ultrastructural studies (e.g., autoradiography and EM) reveal the intracellular or extracellular location of mycoplasmas. The presence of intact organisms in phagolysosomes does not, however, confirm their viability. A major problem in EM experiments is the difficulty of interpreting electronmicrographs because of the similarity between ingested mycoplasmas and
PMNL intracellular organelles. Gold-antibody labelling helps to resolve this; Lo et al ${ }^{\mathbf{8 0 . 8 1}}$ successfully demonstrated $M$. fermentans strain incognitus in diseased tissues by immunochemical staining and EM.

$\mathrm{CL}$ and ${ }^{14} \mathrm{CO}_{2}$ production studies allow measurement of the phagocyte respiratory burst elicited by mycoplasmas, but this is not necessarily an indication that effective phagocytosis and intracellular killing has occurred. Both ${ }^{14} \mathrm{CO}_{2}$ production from glucose-1[14C] and luminol-dependent CL emission indicate that $M$. hominis elicits a sizeable respiratory burst from PMNLs yet viable count studies show killing is relatively inefficient. ${ }^{50-52}$

Viable count studies are potentially of great value as they are the only direct means of measuring the mycoplasmacidal activity of phagocytes. Viable mycoplasma counts before and after low-speed centrifugation of the phagocyte-mycoplasma suspension enable the number of mycoplasmas associated with the phagocyte to be ascertained but do not differentiate between adherent and intracellular mycoplasmas. Parkinson and $\mathrm{Carter}^{55}$ claim that viability studies are unsuitable for assessing the attachment and ingestion of mycoplasmas by phagocytes because of mycoplasma aggregation or disaggregation, transient attachment to the phagocyte and leucocytic sedimentation during the assay.

To count live, intracellular mycoplasmas, phagocytes must be lysed by a technique that does not affect mycoplasma viability. Ice-cold distilled water ${ }^{50}$ and gentle sonication ${ }^{35}$ have both been used successfully; sonication has the added benefit of dispersing mycoplasma aggregates, a source of error in viablecount assays. ${ }^{82}$

\section{Can in-vitro assays be related to in-vivo immune responses?}

The applicability of in-vitro assays of phagocytosis in in-vivo cellular immune responses has been questioned. ${ }^{15,26}$ Discrepancies in phagocytosis of invitro and in-vivo cultured mycoplasmas have been reported. ${ }^{27,75}$ Standardisation of the mycoplasma culture is fundamental to attaining reproducible results. Culture age affects the outcome of the interaction with the phagocytic cell, ${ }^{59}$ probably as a result of changes in mycoplasma affinity for PMNL binding sites and variations in production of metabolites toxic to PMNL during their life cycle. For example, attachment of encapsulated mycoplasmas to phagocytes is likely to vary with capsular size, which depends upon culture age $^{83,84}$ and growth rate. $^{85}$ Qualitative or quantitative changes may occur also in the expression of mycoplasma surface antigens in vivo. Alternatively, host material or non-opsonic antibody may become bound to mycoplasmas and subsequently inhibit the attachment of opsonic antibody or complement. ${ }^{27}$

Howard and Taylor ${ }^{26}$ demonstrated that in-vitro phagocytosis studies could not differentiate avirulent and virulent mycoplasma strains, as defined in vivo. 
This probably reflects the dependence of virulence on a variety of factors, e.g., attachment, antibiotic resistance, production of toxic metabolites etc., rather than on one single determinant. ${ }^{86}$ Krausse et al ${ }^{50,78}$ showed that poor stimulation of PMNL CL was associated with increased virulence of clinical isolates of $U$. urealyticum and a reference strain of $M$. pneumoniae. However, they could not correlate PMNL $\mathrm{CL}$ stimulation with virulence for $M$. hominis. ${ }^{50}$

Studies of the phagocytosis of mycoplasmas attached to host cells rather than in suspension may resemble more closely the in-vivo relationship between phagocytes and mycoplasma. ${ }^{21}$ For other bacteria, CL responses of PMNL depend on whether organisms are adherent to glass or are in suspension. ${ }^{87} \mathrm{~A}$ further problem of in-vitro studies is that PMNL from peripheral blood are not representative of the highly activated PMNL that marginate and migrate through tissues to foci of infection. ${ }^{88}$

The method of opsonisation of mycoplasmas may affect the outcome of phagocytosis. ${ }^{75}$ If mycoplasmas are treated with serum after attaching to phagocytes, some cells may be inaccessible to opsonins ${ }^{76}$ However, serum treatment before mixing with phagocytes results in aggregation, which affects attachment, ingestion and enumeration of mycoplasmas. Reports on other bacteria even suggest that pre-opsonisation may increase resistance to phagocytosis. $^{89}$ Variations in specific antibody titres and complement levels in serum may affect reproducibility. Contradictory data on the capacity of specific antisera to opsonise mycoplasmas effectively may have resulted from the use of nonhomologous sera and cells, ${ }^{27,53,54,61,62,71,75}$ which can lead to erroneous conclusions about the role of cellular immune mechanisms in the natural host. Discrepancies between the opsonising potential of sera from different species may lie in the recognition of different mycoplasma antigens by the respective host immune systems. For example, antibody raised in different hosts may recognise different epitopes of the same M. pneumoniae $\mathrm{P} 1$ adhesin. ${ }^{86}$ Specific immunoglobulin raised against different epitopes of mycoplasma antigens may also have varying opsonic capacity, and nonhomologous anti-mycoplasmal immunoglobulins may bind less efficiently to phagocyte $\mathrm{Fc}$ receptors due to differences in IgG sub-class distribution. ${ }^{22,75}$

Other methodological factors that affect the reproducibility of in-vitro assays include presence of medium components, ${ }^{51,61,64,75}$ variation (or total disregard) in phagocyte-mycoplasma ratios and cell concentrations, ${ }^{51,57,58,77,90}$ incubation times of reaction mixtures, ${ }^{51,56,66}$ impurities of phagocyte preparations $\mathrm{s}^{54,55,75}$ and opsonisation conditions.

\section{Mycoplasma and phagocyte function (figure)}

\section{Attachment}

Mycoplasmas attach to the surface membranes of competent phagocytes and often appear to prolifer- ate. $^{27,50,53,55,76}$ Jones and co-workers ${ }^{66.67}$ found that M. pulmonis multiplied after attachment to the plasma membrane of peritoneal macrophages. Mycoplasmas may withdraw nutrients or gain protection from the action of complement and other serum components by this close association. Failure of $\operatorname{IgG}$ to enhance phagocytosis of $M$. pulmonis has been attributed to the inaccessibility of mycoplasmas within large accumulations of PMNL exudate, and to the concealment of mycoplasmas in the cytoplasmic processes and microvilli of infected cells. ${ }^{53.76}$ The ability of certain mycoplasmas to bind host immunoglobulins non-immunologically through the expression of receptors for the $\mathrm{Fc}$ moiety ${ }^{91.92}$ might also impair phagocytosis. EM shows an intimate association between the plasma membrane of the mycoplasma and that of the phagocyte ${ }^{66}$ with a gap of only c. $5-10 \mathrm{~nm}$ between the juxtapositioned membranes. ${ }^{93}$ Radiolabelling, flow cytometry-immunofluorescence and ELISA studies have provided a wealth of information concerning the ability of mycoplasma cells or antigen to bind the surfaces of both professional and non-professional phagocytes..$^{52.61 .63 .66,72}$ Unfortunately, relatively little is understood of the mechanisms of attachment or the mycoplasma surface moieties that determine the outcome of this interaction. ${ }^{67}$

Hydrophobicity is important in determining the outcome of phagocytosis ${ }^{94}$ bacteria of high hydrophobicity tend to be engulfed more rapidly than those of low hydrophobicity. This phenomenon may be of particular importance to Mycoplasma spp. as their membranes contain large amounts of cholesterol, a highly hydrophobic molecule. ${ }^{95}$ Furthermore, cholesterol is abundant in bronchial secretions ${ }^{96}$ and is bound avidly by mycoplasmas $;{ }^{97}$ the capacity of a mycoplasma to assimilate cholesterol from its environment may thus affect interaction with phagocytes.

Adherence of mycoplasmas to the cell surface probably involves lipoglycans, ${ }^{98}$ which have been found in all species of Acholeplasma, Anaeroplasma and Spiroplasma studied, and in certain species of Mycoplasma. Lipoglycans exhibit both mitogenic and endotoxic properties, and they are thought to be similar in function to bacterial lipopolysaccharides. ${ }^{98}$ At present, PMNL priming by lipoglycans has not been demonstrated; however, mycoplasma-derived high mol. wt material (MDHM) from M. fermentans has been shown to activate murine macrophages ${ }^{99}$ and MDHM, $M$. arginini TUH-14 membrane lipoproteins, as well as $M$. pneumoniae and $M$. pulmonis membranes are known to induce proinflammatory cytokines (i.e., TNF- $\alpha$, IL- $1 \beta$, IL- 6 and IFN- $\gamma) ;{ }^{100-107}$ thus, it seems likely that priming of PMNL or macrophages, or both, does take place.

$M$. pneumoniae and $M$. genitalium mediate attachment to epithelial cells via adhesin proteins, ${ }^{108}$ and sialoglyco-conjugated proteins and lipids are important in the interaction of other mycoplasmas with 


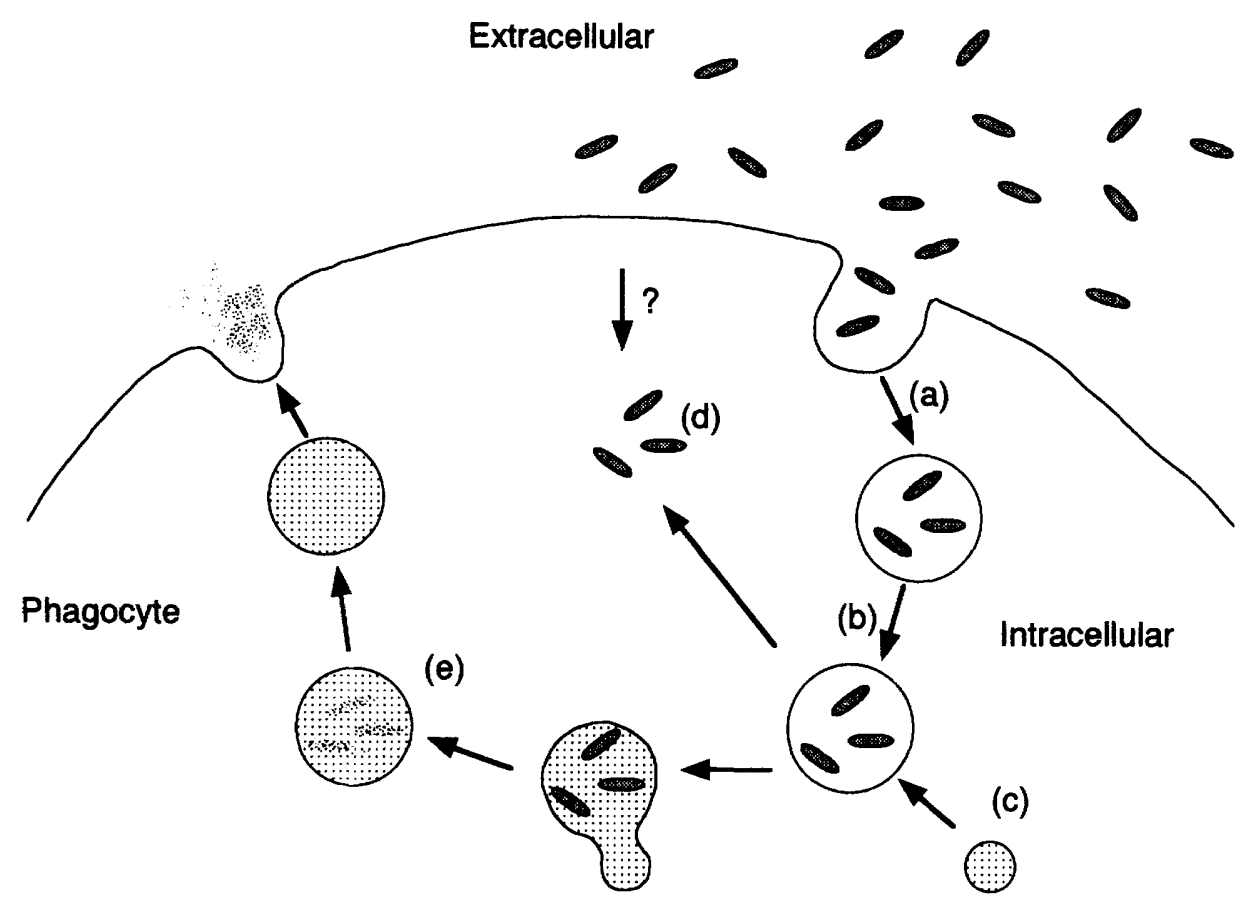

Figure. The stages of phagocytosis that might be circumvented by mycoplasmas. (a) Attachment to and phagocytosis of mycoplasmas may be inhibited by filamentous morphology, presence of antiphagocytic proteins or capsular material, binding of $F c$ portion of immunoglobulin, or localisation of mycoplasmas between cilia and cytoplasmic processes making them inaccessible to phagocytes. (b) Integrity of the phagosome membrane, phagocyte metabolism and activation of the respiratory burst may be affected by mycoplasma proteases, lipases and phospholipases and by oxygen radicals produced by mycoplasmas. (c) Phagosome-lysosome fusion may be impaired by the production of ammonia by mycoplasmas. (d) Mycoplasmas may survive phagocytosis and escape into the cytoplasm (mechanism unknown). (e) Mycoplasma survival following phagosome-lysosome fusion is unlikely.

eukaryotic cells. ${ }^{109,110}$ Glycosidases alter surface properties of mycoplasmas, ${ }^{91}$ but the effect of these enzymes on the attachment and phagocytosis of mycoplasmas has not been investigated.

Attachment of mycoplasmas to the phagocyte membrane may affect the phagocytosis of other bacteria. Phagocytosis and killing of Escherichia coli by PMNL are impaired by the presence of $M$. hominis, ${ }^{52,64} M$. arthritidis ${ }^{64} M$. dispar ${ }^{16}$ or $M$. bovis,${ }^{16}$ adherence of $M$. bovis to bovine PMNL suppresses CL responses to zymosan and phorbol myristate acetate (PMA). ${ }^{72}$ The importance of mycoplasma viability in the suppression of phagocyte function is disputed, but this may reflect methodological differences. ${ }^{16,72}$ Adherence of mycoplasmas to the PMNL surface may result in interference with the exposed functional domain of the NADPH oxidase complex. ${ }^{72}$ Alternatively, mycoplasmal attachment may prevent binding of other bacteria by the phagocyte, although adherence of $E$. coli to phagocytes is unaffected by pre-incubation of phagocytes with $M$. bovis at concentrations that inhibit bacterial killing. ${ }^{16}$ Flow cytometric studies may help to determine whether pre-incubation of PMNL with mycoplasmas interferes with the adherence of particulate targets or their subsequent ingestion, or both. ${ }^{72}$

\section{Phagocytosis}

Bar-shavit et al. ${ }^{111}$ found filaments of $E$. coli to be internalised less efficiently than coccoid bacteria by phagocytic cells, although this was overcome by opsonisation. Similar observations have been made with mycoplasmas; exponential phase $M$. mycoides subsp. capri cells (predominantly filamentous), elicit reduced CL responses from PMNL when compared with younger or older cells (predominantly nonfilamentous) ${ }^{59}$ treatment of exponential-phase mycoplasmas with non-specific opsonins reverses these differences. Perhaps filamentous mycoplasmas have a non-homogeneous distribution of binding proteins that, in the absence of opsonins, prevents efficient interaction with the phagocyte surface and the circumferential interaction required for the engulfment stage. ${ }^{112,113}$

Studies with trypsin suggest the presence of an antiphagocytic surface protein on M. pulmonis ${ }^{67.69}$ Following treatment with trypsin $(100 \mu \mathrm{g} / \mathrm{ml})$ the organism was more susceptible to phagocytosis by murine macrophages when observed under phase contrast microscopy ${ }^{67,114}$ or by scanning EM. ${ }^{69}$

Many mycoplasmas possess a capsule, as determined by ruthenium red staining or EM, ${ }^{114}$ and several reports suggest their importance in resistance to phagocytosis. Capsules reduce mycoplasma cell surface hydrophobicity, increasing resistance to phagocytosis. Recent studies have demonstrated that bovine lung fibroblasts induce proliferation of the galactan that encapsulates $M$. dispar, ${ }^{115,116}$ this results in inhibition of the bactericidal and secretory functions of bovine alveolar macrophages. ${ }^{115}$ Both capsulate organisms and purified capsule preparations suppress tumour necrosis factor $\alpha$ (TNF- $\alpha$ ) production, IL-1 production and glucose consumption by macrophages. ${ }^{115}$ 
The M. mycoides subsp. mycoides galactan capsule may also stimulate TNF- $\alpha$, as large colony strains of this species induce TNF- $\alpha$ production in infected goats. ${ }^{115}$ Non-capsulate $M$. mycoides cells are more susceptible to non-specific opsonisation ${ }^{59}$ probably as a result of decreased complement deposition. However, the capacity of capsulate $M$. mycoides strains to impair binding of opsonins to the cell surface does not appear to be shared by many other Mycoplasma species. Most mycoplasmas both bind antibody rapidly and activate complement by either the alternative $^{56,117,118}$ or the classical ${ }^{118-127}$ pathways, as well as interacting with the $\mathrm{Cl}$ component directly. ${ }^{51,128}$

\section{PMNL membrane damage}

Mycoplasma-mediated damage to the phagocyte membrane may occur in several ways. Proteases associated with the mycoplasma membrane ${ }^{129}$ may damage phagocyte membrane integrity. The action of mycoplasma lipases or phospholipases ${ }^{130,131}$ on the cell surface may reduce phagocytic function either by generating lipid hydrolysis products, ${ }^{72}$ such as sphingosines (potent inhibitors of NADPH oxidase activity ${ }^{132}$ ), or by altering membrane fluidity, ${ }^{133}$ one of several factors important in the activation of the PMNL respiratory burst. ${ }^{133}$

Mycoplasma oxygen radical production, by damaging the phagocyte membrane, may act as a pathogenicity factor. ${ }^{134-138}$ Generation of these oxygen metabolites in close proximity to the PMNL surface may be important in allowing oxidation of PMNL membrane lipid components, ${ }^{136}$ thereby affecting membrane fluidity and resulting in the formation of cytotoxic metabolites, such as malonyldialdehyde. ${ }^{134}$ Membrane lipid peroxidation via arachidonic acid is also the first stage in a whole spectrum of PMNL metabolic pathways which result in the production of leukotrienes and prostaglandins, two important groups of cytokines involved in inflammatory and cellular immune responses. Mycoplasma radical production may disrupt these and other metabolic pathways, such as the glutathione redox cycle ${ }^{136,139}$ glutathione synthesis is coupled with respiratory burst activity in PMNL ${ }^{140}$ and glutathione depletion as a result of mycoplasma oxidative attack might affect PMNL bactericidal capacity. Mycoplasma oxygen radical generation may result in premature inactivation of the PMNL NADPH oxidase, which is sensitive to oxidation by superoxide ion $\left(\mathrm{O}_{2}{ }^{-}\right) \cdot{ }^{141}$ Phorbol mystrate acetate (PMA) by-passes receptormediated transmembrane signalling, acting directly on protein kinase $\mathrm{C}$; the inhibition of PMA-induced $\mathrm{CL}$ by $M$. bovis implies that interference with NADPH oxidase activation must occur at the level of protein kinase $\mathrm{C}$ activation or later in the pathway. ${ }^{72}$

$M$. fermentans strain incognitus has been shown to damage PMNL (and lymphocyte) membranes, as measured by the trypan blue method. ${ }^{74}$ However, in this case, damage to the phagocyte membrane is probably not attributable to autonomous production of oxygen radical, as $M$. fermentans strain incognitus induces only a relatively weak CL response from PMNL. In contrast, M. fermentans PG18 and M. felis elicit substantial PMNL CL responses, but only mildly affect PMNL membrane integrity.

\section{Intracellular survival}

Evidence for the survival of mycoplasmas within phagocytes is contradictory; this may reflect the fact that survival depends on the mechanisms by which mycoplasmas are phagocytosed. Antibody-mediated phagocytosis results almost invariably in ingestion and killing of Mycoplasma spp. by phagocytic cells. ${ }^{51,63}$ In contrast, complement-mediated phagocytosis results in less effective killing of mycoplasmas. ${ }^{50-52.59}$ In-vivo studies have demonstrated intracellular mycoplasmalike inclusions in mononuclear interstitial cells which stained positive for $M$. fermentans strain incognitus antigens. ${ }^{2}$ Lo et al. ${ }^{142}$ identified $M$. fermentans strain incognitus in various cell and tissue types, including peripheral blood monocytes, by DNA hybridisation. The mechanism of entry to the PMNL cytoplasm is unknown, but may involve complement receptors; cellular uptake via CR3 avoids the triggering of some PMNL microbicidal mechanisms and is a strategy employed by a number of intracellular pathogens. ${ }^{143}$

If mycoplasmas can exist intracellularly within phagocytes, how do they escape phagocyte bactericidal mechanisms? Resistance of mycoplasmas to oxygen radicals and chloramines generated by phagocytes during the respiratory burst is hard to explain, as these organisms are sensitive to the same oxygen radicals generated in cell-free systems. ${ }^{144,145}$ The close proximity of mycoplasmas to the phagocyte membrane may be in some way protective. ${ }^{76}$ Serum is an effective scavenger of $\mathrm{H}_{2} \mathrm{O}_{2}$ and binding of serum components, such as catalase, by mycoplasmas ${ }^{97}$ might account for the resistance of serum-treated cells to phagocyte oxidative attack. Mycoplasmas themselves produce substantial amounts of active oxygen radicals and may thus possess efficient enzymic processes for their inactivation. However, reports of catalase and superoxide dismutase (SOD) activity in mycoplasmas are conflicting, ${ }^{68,137,146}$ and it seems unlikely they have sufficiently high levels of such enzymes to avoid damage by phagocyte oxygen radicals. Furthermore, levels of SOD and catalase production do not correlate with virulence or resistance to phagocytic killing for other bacteria. ${ }^{147}$ Alternative mechanisms by which mycoplasmas may avoid phagocytic killing include inhibition of myeloperoxidase, and detoxification of oxidants via reducing agents secreted or exposed on the mycoplasma surface.

Resistance of mycoplasmas to non-oxidative microbicidal mechanisms of phagocytes is poorly understood. M. pulmonis elicits the release of hydrolytic enzymes from macrophages, suggesting that mycoplasmas are exposed to attack by serine proteases 
and defensins. ${ }^{90}$ Erb and Bredt $^{76}$ proposed that the high lipid content of mycoplasma membranes might protect against phagocyte intraphagosomal components but found no evidence for this. Lysosomal enzymes, such as lysozyme, would have little effect on mycoplasmas as they lack a cell envelope. ${ }^{50}$ On the other hand, the lack of a cell wall predisposes mycoplasmas to direct attack by other lysosomal enzymes. The sensitivity of mycoplasmas to PMNL lysates and intracellular killing mechanisms of PMNL in vitro suggests that inherent resistance to nonoxidative killing is unlikely. ${ }^{52,148.149}$

Ammonia may interfere with phagosome-lysosome fusion in $P M N^{150,151}$ and its production by mycoplasmas has been proposed as a virulence factor. ${ }^{152,153}$ Ammonia is formed by the hydrolysis of urea by ureaplasmas, and of L-arginine by many Mycoplasma spp. Furthermore, as these reactions are major or sole sources of energy generation in the species concerned, large quantities of substrate will be consumed during growth. Reduced availability of Larginine can affect the metabolism of mammalian cells and, in particular, the biosynthesis ${ }^{154}$ of nitric oxide. Macrophage-derived nitric oxide is involved in tumour cell cytostasis ${ }^{155}$ and the killing or inhibition of growth of bacteria. ${ }^{156}$ Thus, arginine-utilising mycoplasmas (e.g., M. hominis and $M$. fermentans) may disrupt phagocyte bactericidal capacity.

\section{Conclusions}

A number of conclusions can be drawn from the current extent of our knowledge of the phagocytemycoplasma interaction and its implications in the wider context of mycoplasma pathogenicity.

First, the presence of opsonins is important in determining the fate of the mycoplasma following interaction with the phagocyte. Opsonisation by specific antibody results almost invariably in the rapid phagocytosis and destruction of the mycoplasma. Further work is required to determine if this is a result of antibody neutralisation of mycoplasma antiphagocytic mechanisms, increased aggregation of mycoplasmas, increased efficiency of Fc receptormediated phagocytosis, or a combination of factors. The outcome of complement-mediated phagocytosis is less clear; recent studies suggest that non-specifically opsonised cells are phagocytosed, but some may escape bactericidal mechanisms. The state of priming or activation of the phagocytic cell is likely to be important in determining the success of non-specific phagocytosis of mycoplasmas. Recent evidence suggests that the NADPH oxidase of activated cells produces enhanced amounts of $\mathrm{H}_{2} \mathrm{O}_{2}$ and superoxide ion. ${ }^{157}$ In addition, the increased expression of membrane receptors and the enhanced efficiency of degranulation results in the more effective bacterial killing observed with activated phagocytes. The importance of priming on phagocyte function emphasises the need to study the effect of Mycoplasma spp. on host cytokine production, ${ }^{102.158}$ and in turn the effects of these cytokines on phagocyte function. ${ }^{115,116}$

Second, the type and origin of the phagocyte encountered by a mycoplasma is important in determining its subsequent survival. Both PMNL and mononuclear phagocytes can phagocytose mycoplasmas effectively in the presence of antibody, providing it is of the right idiotype-isotype. However, they may differ in their ability to kill mycoplasmas in the absence of antibody. Furthermore, NK cells, rather than PMNL or macrophages, have been reported to be responsible for mycoplasmacidal activity in the respiratory tract of mice. ${ }^{31.46 .47}$ Future studies should investigate the role of different cell types in resistance to mycoplasma infection in the nonimmune host.

Finally, the assumption that mycoplasmas are phagocytosed in the host only after an antibody response must be re-evaluated. Many investigators have disregarded the role of complement or other nonspecific opsonins. Mycoplasma infection results in a massive increase in localised concentrations of complement components in bronchial secretions. ${ }^{159}$ Increased vascular permeability during inflammation would be expected to elevate levels of complement further. In addition, a distinct functionally active leucocyte complement system exists on the surface of macrophages and lymphocytes, ${ }^{90.160}$ and macrophages co-operate with PMNL in phagocytosis in vitro by providing opsonins. ${ }^{161}$ This evidence suggests strongly that mycoplasmas are exposed to complement, even at extracellular mucosal sites, in the non-immune host. Therefore, the use of unopsonised cells in in-vitro studies to represent the interaction of mycoplasmas with phagocytes in the non-immune host is inappropriate.

Recent studies highlight the susceptibility of patients with antibody deficiency to mycoplasma infection. ${ }^{51,162}$ The emergence of mycoplasmas as opportunists in HIV infections, ${ }^{1.5}$ where antibody levels are also depleted, is of particular note. The capacity of mycoplasmas to impair the phagocytosis of other bacteria in vitro emphasises their possible role as copathogens with chlamydiae, meningococci and HIV.

The ability of some pathogenic mycoplasmas to avoid killing in the presence of complement and PMNL is important to understanding the pathogenesis of mycoplasma infections. Enhanced PMNL oxidative activity in the presence of complement-opsonised mycoplasmas may result in alveolar damage ${ }^{163}$ and may account for the necrotic nature of lesions associated with mycoplasma infection. ${ }^{21}$ Webster et al. ${ }^{51}$ even go so far as to suggest that phagocytosis of pathogenic mycoplasmas in the absence of antibody may be an important factor in the dissemination of mycoplasma disease.

The interaction between mycoplasmas, phagocytes and complement components, and their influence on recovery from mycoplasma disease are extremely 
complex. Further study of the mechanisms involved in the mycoplasma-phagocyte interaction, and of the genetic basis for phagocytic competence against these bacteria, will enable us to understand more fully the

\section{References}

1. Lo S-C, Dawson MS, Wang DM et al. Identification of Mycoplasma incognitus infection in patients with AIDS: an immuno-histochemical, in situ hybridization and ultrastructural study. Am J Trop Med Hyg 1989; 41 : 601-616.

2. Bauer FA, Wear DJ, Angritt P, Lo S-C. Mycoplasma fermentans (incognitus strain) infection in the kidneys of patients with acquired immunodeficiency syndrome and associated nephropathy: a light microscopic, immunohistochemical, and ultrastructural study. Hum Pathol 1991; 22: 63-69.

3. Taylor-Robinson D, Davies HA, Saranthchandra P, Furr PM Intracellular location of mycoplasmas in cultured cells demonstrated by immunocytochemistry and electron microscopy. Int J Exp Pathol 1991; 72: 705-714.

4. Franzoso G, Dimitrov DS, Blumenthal R, Barile MF, Rottem S. Fusion of Mycoplasma fermentans strain incognitus with T-lymphocytes. FEBS Lett 1992; 303: 251-254.

5. Lo, S-C, Hayes MM, Tully JG et al. Mycoplasma penetrans sp. nov., from the urogenital tract of patients with AIDS. Int $J$ Syst Bacteriol 1992; 42: 357-364.

6. Phillips DM, Pearce-Pratt $R$, Tan X, Zacharopoulos VR. Association of mycoplasma with HIV-1 and HTLV-1 in human T lymphocytes. AIDS Res Hum Retroviruses 1992; 8: $1863-1868$

7. Lo, S-C, Tsai S, Benish JR, Shih JW-K, Wear DJ, Wong DM Enhancement of HIV-1 cytocidal effects in $\mathrm{CD}^{+}$ lymphocytes by the AIDS-associated mycoplasma. Science 1991 : 251: 1074-1076.

8. Montagnier L. AIDS pathogenesis. Biochemist 1990; 13: 3-7.

9. Lemaitre M, Henin Y, Destouesse F, Ferrieux C, Montagnier $\mathrm{L}$, Blanchard A. Role of mycoplasma infection in the cytopathic effect induced by human immunodeficiency virus type 1 in infected cell lines. Infect Immun 1992; 60: 742-748.

10. Moore PS, Hierholzer J, Dewitt W et al. Respiratory viruses and mycoplasmas as cofactors for epidemic group- $\mathrm{A}$ meningococcal meningitis. JAMA 1990; 264: 1271-1275.

11. Hierholzer JC, Moore P, Broome CV. Mycoplasma and epidemic group A meningococcal meningitis. JAMA 1991; 265: 212.

12. Sherman KJ, Daling JR, Stergachis A et al. Sexually transmitted diseases and tubal pregnancy. Sex Transm Dis 1990; 17: 115-121.

13. Hahn DL, Dodge RW, Golubjatnikov R. Association of Chlamydia pneumoniae (strain TWAR) infection with wheezing, asthmatic bronchitis, and adult-onset asthma. JAMA 1991; 266: 225-230.

14. Sibille Y, Reynolds HY. Macrophages and polymorphonuclear neutrophils in lung defense and injury. Am Rev Respir Dis 1990; 141: 471-501.

15. Howard CJ, Taylor G. Humoral and cell-mediated immunity. In: Razin S, Barile MF (eds) The mycoplasmas, vol 4; Mycoplasma pathogenicity. London, Academic Press. 1985: 259-292.

16. Howard CJ, Taylor G. Interaction of mycoplasmas and phagocytes. Yale J Biol Med 1983; 56: 643-648.

17. Cole BC, Naot Y, Stanbridge EJ, Wise KS. Interactions of mycoplasmas and their products with lymphoid cells in vitro. In: Razin S, Barile MF (eds) The mycoplasmas, vol 4. Mycoplasma pathogenicity. London, Academic Press. 1985: 203-257.

18. Cassell GH, Lindsey JR, Overcash RG, Baker HJ. Murine mycoplasma respiratory disease. Ann N Y Acad Sci 1973; 225: $395-412$

19. Lindsey JR, Cassell GH. Experimental Mycoplasma pulmonis infection in pathogen-free mice. Models for studying mycoplasmosis of the respiratory tract. Am J Pathol 1973; 72: $63-90$ ways in which mycoplasmas cause disease in nonimmune and immunocompromised hosts.

The award of an SERC postgraduate studentship to A.M. is gratefully acknowledged.

20. Cole BC, Washburn LR, Taylor-Robinson D. Mycoplasmainduced arthritis. In: Razin S, Barile MF (eds) The mycoplasmas, vol 4. Mycoplasma pathogenicity. London. Academic Press. 1985: 107-160.

21. Cassell GH, Clyde WA, Davis JK. Mycoplasma respiratory infections. In: Razin S, Barile MF (eds) The mycoplasmas. vol 4. Mycoplasma pathogenicity. London, Academic Press. 1985: 66-99.

22. Cassell GH, Lindsey JR, Baker HJ. Immune response of pathogen-free mice inoculated intranasally with Mycoplasma pulmonis. J Immunol 1974; 112: 124-136.

23. Taylor G, Taylor-Robinson D. The part played by cell-mediated immunity to mycoplasma respiratory infections. Dev Biol Stand 1975; 28: 195-210.

24. Brownlie J, Howard CJ, Gourlay RN. Pathogenicity of certain Mycoplasma species in the bovine mammary gland. Res Vet Sci 1976; 20 : 261-266.

25. Brownlie J, Howard CJ, Gourlay RN. The effect of an intramammary infusion of endotoxin on experimentally induced mycoplasma mastitis. J Hyg 1979; 83: 501-505.

26. Howard CJ, Taylor G. Variation in the virulence of strains of Mycoplasma pulmonis related to susceptibility to killing by macrophages in vivo. J Gen Microbiol 1979; 114: 289-294.

27. Taylor G, Howard CJ. Interaction of Mycoplasma pulmonis with mouse peritoneal macrophages and polymorphonuclear leukocytes. J Med Microbiol 1980; 13: 19-30.

28. Davis JK, Parker RF, White $\mathrm{H}$ et al. Strain differences in susceptibility to murine respiratory mycoplasmosis in $\mathrm{C} 57 \mathrm{BL} / 6$ and $\mathrm{C} 3 \mathrm{H} / \mathrm{HeN}$ mice. Infect Immun $1985 ; 50$ : $647-654$.

29. Thomas LH, Howard CJ, Stott EJ, Parsons KR. Mycoplasma bovis infection in gnotobiotic calves and combined infection with respiratory syncytial virus. Vet Pathol 1986; 23: $571-578$

30. Simecka JW, Davis JK, Cassell GH. Specific vs. nonspecific immune responses in murine respiratory mycoplasmosis. Isr J Med Sci 1987; 23: 485-489.

31. Davidson MK, Davis JK, Lindsey JR, Cassell GH. Clearance of different strains of Mycoplasma pulmonis from the respiratory tract of $\mathrm{C} 3 \mathrm{H} / \mathrm{HeN}$ mice. Infect Immun 1988: 56: $2163-2168$

32. Simecka JW, Davis JK, Cassell GH. Serum antibody does not account for differences in the severity of chronic respiratory disease caused by Mycoplasma pulmonis in LEW and F344 rats. Infect Immun 1989; 57: 3570-3575.

33. Meier B, Binder A, Herold S et al. Demonstration of substances with activating, chemotactic and aggregating properties for PMNs released by Mycoplasma arthritidis. Int J Med Microbiol 1990; 274 Suppl 20: 593-597.

34. Komatsu S. Eosinophil chemotaxis to $M$. pneumoniae. IOM Lett 1990; 1: 322-323.

35. Davis JK, Parker RF, Davidson MK, Cassell GH, Lindsey RL. Pulmonary clearance of Mycoplasma pulmonis in mice. Int $J$ Med Microbiol 1990; 274 Suppl 20:819-822.

36. Davidson MK, Davis JK, Cassell GH, Lindsey JR. Variation in virulence mechanisms of Mycoplasma pulmonis. IOM Lett $1990 ; 1: 195-196$.

37. Davis JK, Davidson MK, Schoeb TR. Intrapulmonary killing of Mycoplasma pulmonis in mice. IOM Lett 1990: 1: 347-348.

38. Davis JK, Davidson MK, Schoeb TR. Murine respiratory mycoplasmosis: a model to study effects of oxidants. Res Rep Health Eff Inst 1991; 47: 1-43.

39. Davis JK, Davidson MK, Schoeb TR, Lindsey JR. Decreased intrapulmonary killing of Mycoplasma pulmonis after short-term exposure to $\mathrm{NO}_{2}$ is associated with damaged alveolar macrophages. Am Rev Respir Dis 1992; 145: $406-411$.

40. Ross SE, Simecka JW, Gambill GP, Davis JK, Cassell GH. Mycoplasma pulmonis possesses a novel chemoattractant for B lymphocytes. Infect Immun 1992; 60: 669-674. 
41. Kaklamani E, Karalis D, Kaklamanis $\mathbf{P}$ et al. The effect of Mycoplasma arthritidis infection on the phagocytic activity of macrophages in rats and mice. FEMS Microbiol Immunol 1991; 3: 151-158.

42. Kaklamani E, Karalis D, Koumandaki Y et al. The effect of Mycoplasma arthritidis infection on the kinetics of colloidal clearance in mice. FEMS Immunol Med Microbiol 1993; 6: 299-305.

43. Lai WC, Linton G, Bennett M, Pakes SP. Genetic control of resistance to Mycoplasma pulmonis infection in mice. Infect Immun 1993; 61 : 4615-4621.

44. Ohlsson A, Wang E, Vearncombe M. Leukocyte counts and colonization with Ureaplasma urealyticum in preterm neonates. Clin Infect Dis 1993; 17 Suppl 1: S144-S147.

45. Lai WC, Bennett M, Pakes SP et al. Resistance to Mycoplasma pulmonis mediated by activated natural killer cells. J Infect Dis 1990; 161: 1269-1275.

46. Lai WC, Pakes SP, Lu YS, Brayton CF. Mycoplasma pulmonis infection augments natural killer cell activity in mice. $J \mathrm{Lab}$ Anim Sci 1987; 37: 299-303.

47. Lai WC, Bennett M, Pakes SP. Mycoplasma pulmonis infection activates natural killer cells, which help inactivate Mycoplasma pulmonis organisms. Int $J$ Med Microbiol 1990; 274 Suppl 20: 709-712.

48. Lai WC, Bennett M, Pakes SP. Modulation of natural killer cell function and delayed type hypersensitivity responses in mice infected with Mycoplasma pulmonis. IOM Lett 1990 1: $131-132$.

49. Parker RF, Davis JK, Blalock DK, Thorp RB, Simecka JW, Cassell GH. Pulmonary clearance of Mycoplasma pulmonis in C57BL/6 and C3H/HeN mice. Infect Immun 1987; 55 2631-2635.

50. Krausse $\mathrm{R}$, Ullman $\mathrm{U}$, Wagener $\mathrm{C}$. In vitro influence of mycoplasma species on the stimulation of human polymorphonuclear granulocytes. Zentralbl Bakteriol Mikrobiol Hyg A 1988; 270: 228-236.

51. Webster AD, Furr PM, Hughes-Jones NC, Gorick BD, TaylorRobinson D. Critical dependence on antibody for defence against mycoplasmas. Cl Exp Immunol 1988; 71 : 383-387.

52. Simberkoff MS, Elsbach $\mathrm{P}$. The interaction in vitro between polymorphonuclear leukocytes and mycoplasma. $J$ Exp Med 1971; 134: 1417-1430.

53. Cole BC, Ward JR. Interaction of Mycoplasma arthritidis and other mycoplasmas with murine peritoneal macrophages. Infect Immun 1973; 7: 691-699.

54. Howard CJ, Taylor G, Collins J, Gourlay RN. Interaction of Mycoplasma dispar and Mycoplasma agalactiae subsp. bovis with bovine alveolar macrophages and bovine lactea polymorphonuclear leukocytes. Infect Immun 1976; 14: $11-17$.

55. Parkinson CF, Carter PB. Phagocytosis of Mycoplasma salivarium by human polymorphonuclear leukocytes and monocytes. Infect Immun 1975; 11: 405-414.

56. Bredt W. Phagocytosis by macrophages of Mycoplasma pneumoniae after opsonization by complement. Infect Immun 1975; 12: 694-695.

57. Zucker-Franklin D, Davidson $M$, Thomas $L$. The interaction of mycoplasmas with mammalian cells. I. HeLa cells, neutrophils, and eosinophils. $J$ Exp Med 1966; 124: 521-532 (+ plates 39-43).

58. Zucker-Franklin D, Davidson M, Thomas L. The interaction of mycoplasmas with mammalian cells. II. Monocytes and lymphocytes. $J$ Exp Med 1966; 124: 533-542 (+ plates 44-51).

59. Marshall AJ. An in vitro study of the role of phagocytosis and serum factors in cellular and humoral immunity to mycoplasma infection. PhD Thesis, University of London. 1992.

60. Barile MF, Yoshida H, Roth H. Rheumatoid arthritis: new findings on the failure to isolate or detect mycoplasmas by multiple cultivation or serologic procedures and a review of the literature. Rev Infect Dis 1991 ; 13: 571-582.

61. Busolo F, Tonellato L, Scremin L, Tonin E, Bertolini G, Franceschi C. Phagocytosis of Mycoplasma pneumoniae and Acholeplasma laidlawii measured as inhibition of [H-3] uridine uptake by macrophages. J Immuno Methods 1986 ; 90: $235-240$

62. Powell DA, Clyde WA. Opsonin-reversible resistance of Mycoplasma pneumoniae to in vitro phagocytosis by alveolar macrophages. Infect Immun 1975; 11 : 540-550.
63. Kist M, Jacobs E, Bredt W. Release of Mycoplasma pneumoniae substances after phagocytosis by Guinea Pig alveolar macrophages. Infect Immun 1982; 36: 357-362.

64. Thomsen AC, Heron I. Effect of mycoplasmas on phagocytosis and immunocompetence in rats. Acta Pathol Microbiol Scandi $[C] 1979 ; 87: 67-71$.

65. Powell DA, Muse KA. Scanning electron microscopy of guinea pig alveolar macrophages: in vitro phagocytosis of Mycoplasma pneumoniae. Lab Invest 1977; 37: 535-543.

66. Jones TC, Hirsch JG. The interaction in vitro of Mycoplasma pulmonis with mouse peritoneal macrophages and L-cells. J Exp Med 1971; 133: 231-259.

67. Jones TC, Yeh S, Hirsch JG. Studies on attachment and ingestion phases of phagocytosis of Mycoplasma pulmonis by mouse peritoneal macrophages. Proc Soc Exp Biol Med 1972; 139: 464470 .

68. Organick AB, Siegesmund KA, Lutsky II. Pneumonia due to mycoplasma in gnotobiotic mice. II. Localization of Mycoplasma pulmonis in the lungs of infected gnotobiotic mice by electron microscopy. J Bacteriol 1966; 92: 1164-1176.

69. Jones TC, Minick RC, Yang L. Attachment and ingestion of mycoplasmas by mouse macrophages. II. Scanning electron microscopic observations. Am J Pathol 1977; 87: 347-358

70. Al-Kaissi A, Alley MR. Electron microscopic studies of the interaction between ovine alveolar macrophages and Mycoplasma ovipneumoniae in vitro. Vet Microbiol 1983; 8: 577-584.

71. Jones TC, Yang L. Attachment and ingestion of mycoplasmas by mouse macrophages. I. Kinetics of the interaction and effects on phagocyte glucose metabolism. Am $J$ Pathol $1977 ; 87: 331-345$.

72. Thomas CB, Van Ess P, Wolfgram LJ, Riebe P, Sharp P, Schultz RD. Adherence to bovine neutrophils and suppression of neutrophil chemiluminescence by Mycoplasma bovis. Vet Immunol Immunopathol 1991; 27: 365-381.

73. Ferronha MH, Correia I, Trindade H, Carvalho $\mathbf{M H}$, Sousa Ferreira H. Does Mycoplasma mycoides subsp. mycoides activate bovine phagocytes by inducing the oxidative burst? IOM Lett 1994; 3: 645-646.

74. Marshall A, Miles RJ, Richards L. Contrasting effects of Mycoplasma fermentans and $M$. felis on the viability and chemiluminescence response of human polymorphonuclear leukocytes. FEMS Microbiol Lett 1993; 109: $167-171$.

75. Davis JK, Delozier KM, Asa K, Minion FC, Cassell GH. Interactions between murine alveolar macrophages and Mycoplasma pulmonis in vitro. Infect Immun 1980; 29: 590-599.

76. Erb P, Bredt W. Interaction of Mycoplasma pneumoniae with alveolar macrophages: viability of adherent and ingested mycoplasmas. Infect Immun 1979; 25: 11-15.

77. Peterhans E, Bertoni G, Koppel P, Wyler R, Keller R. Antibody-free target cells stimulate chemiluminescence in polymorphonuclear leukocytes: an artifact due to mycoplasma contamination. Eur J Immunol 1984; 14: 201-203.

78. Krausse R, Franke S, Ullmann U. Granulocytes response to $U^{\prime}$. urealyticum: stimulation and killing. IOM Lett 1990; 1 : 324-325.

79. Marshall AJ, Miles RJ, Richards L. The resistance of mycoplasmas to phagocytosis and serum killing. IOM Lett 1990; 1: 54-55.

80. Lo SC, Dawson MS, Newton PB et al. Association of the viruslike infectious agent originally reported in patients with AIDS with acute fatal disease in previously healthy nonAIDS patients. Am J Trop Med Hyg 1989; 41: 364-376.

81. Lo SC, Dawson MS, Wang DM et al. Identification of Mycoplasma incognitus infection in patients with AIDS: an immunohistochemical, in situ hybridization and ultrastructural study. Am $J$ Trop Med Hyg 1989; 41: 601-616.

82. Pirt SJ. The principles of microbe and cell cultivation. London, Blackwell Scientific Publications. 1975: 22-29.

83. Jones AS, Tittensor JR, Walker RT. The chemical composition of the nucleic acids and other macromolecular constituents of Mycoplasma mycoides var. capri. J Gen Microbiol. 1965; 40: 405-411.

84. Schiefer H-G, Gerhardt, U, Brunner H, Krüpe M. Studies 
with lectins on the surface carbohydrate structures of mycoplasma membranes. J Bacteriol 1974; 120: 81-88.

85. Henderson CL, Miles RJ. Growth of Mycoplasma mycoides ssp. mycoides in chemostat culture: effect of growth rate upon cell structure. Int J Med Microbiol 1990; 274 Suppl. 20 945-947.

86. Jacobs E. Mycoplasma pneumoniae virulence factors and the immune response. Rev Med Microbiol 1991; 2: 83-90.

87. Hayashi K, Lee DA, Quie PG. Chemiluminescent response of polymorphonuclear leukocytes to Streptococcus pneumoniae and Haemophilus influenzae in suspension and adhered to glass. Infect Immun 1986; 52: 397-400.

88. Gallin JI. Human neutrophil heterogeneity exists, but is it meaningful? Blood 1984; 63: 977-983.

89. Gargan RA, Brumfitt W, Hamilton-Miller JMT. Preopsonisation of Escherichia coli induces resistance to neutrophil killing in serum and urine: relationship to growth phase. J Med Microbiol 1991; 35: 12-17.

90. Taylor-Robinson D, Schorlemmer HU, Furr PM, Allison AC Macrophage secretion and the complement cleavage product $\mathrm{C} 3 \mathrm{a}$ in the pathogenesis of infections by mycoplasmas and L-forms of bacteria and in immunity to these organisms. Clin Exp Immunol 1978; 33: 486-494.

91. Lemke H, Krausse R, Lorenzen J, Havsteen B. Mycoplasma infection of cell lines can stimulate the expression of $\mathrm{Fc}$ receptors by binding of the carbohydrate moiety of antibodies. Eur J Immunol 1985; 15: 442-447.

92. Alexander AG, Lowes HR, Kenny GE. Identification of a mycoplasmal protein which binds immunoglobulins nonimmunologically. Infect Immun 1991; 59: 2147-2151.

93. Razin S. Mycoplasma adherence. In: Razin S, Barile MF (eds) The mycoplasmas, vol 4. Mycoplasma pathogenicity. London, Academic Press. 1985: 161-202.

94. Van Oss CJ. Phagocytosis as a surface phenomenon. Ann Rev Microbiol 1978; 32: 19-39.

95. Watanabe T, Kumazawa T. Detection of immunoglobulin $G$ antibodies to cholesterol in antisera to mycoplasmas. Infect Immun 1991; 59: 2200-2202.

96. Reynolds HY, Thompson RE. Pulmonary host defenses: I Analysis of protein and lipids in bronchial secretions and antibody responses after vaccination with Pseudomonas aeruginosa. J Immunol 1973; 111: 358-368.

97. Razin S, Rottem S, Hazin M, Gershfeld NL. Binding of exogenous proteins and lipids to mycoplasma membranes. Ann N Y Acad Sci 1973; 225: 28-37.

98. Smith PF. Antigenic character of membrane lipoglycans from Mollicutes-a review. Isr J Med Sci 1987; 23: 448-452.

99. Ruschmeyer D, Thude H, Mülrahdt PF. MDHM, a macrophage-activating product from Mycoplasma fermentans, stimulates murine macrophages to synthesize nitric oxide and become tumoricidal. FEMS Immunol Med Microbiol 1993; 7: 223-229.

100. Mülrahdt PF, Schade U. MDHM, a macrophage-stimulatory product of Mycoplasma fermentans, leads to in vitro interleukin-1 (IL-1), IL-6, tumor necrosis factor, and prostaglandin production and is pyrogenic in rabbits. Infect Immun 1991; 59: 3969-3974.

101. Rawadi G, Roman-Roman S. Cytokine induction by Mycoplasmas on human monocytic cell lines. IOM Lett $1994 ; 3: 660-661$.

102. Pietsch K, Ehlers S, Jacobs E. Cytokine gene expression in the lungs of BALB/c mice during primary and secondary intranasal infection with Mycoplasma pneumoniae. Microbiology 1994; 140: 2043-2048.

103. Meseguer M, Pacheco A, Baquero F, Bricio MT. Induction of tumour necrosis factor-alpha by Mycoplasma pneumoniae on human alveolar macrophages. IOM Lett 1994; 3 : $652-653$.

104. Herbelin A, Ruuth E, Delorme D, Michel-Herbelin C, Praz F. Mycoplasma arginini TUH-14 membrane lipoproteins induce production of interleukin-1, interleukin- 6 and tumor necrosis factor alpha by human monocytes. Infect Immun 1994; 62: 4690-4694.

105. Mülrahdt PF, Frisch M. Purification and partial biochemical characterization of a Mycoplasma fermentans-derived substance that activates macrophages to release nitric oxide, tumor necrosis factor, and interleukin-6. Infect Immun 1994; 62: 3801-3807.

106. Kostyal DA, Butler GH, Beezhold DH. A 48-kilodalton Mycoplasma fermentans membrane protein induces cytokine secretion by human monocytes. Infect Immun 1994; 62: 3793-3800.

107. Nishimoto $M$, Akashi $K$, Kuwano $K$, Tseng CC, Ohizumi $K$, Arai S. Gene expression of tumor necrosis factor alpha and interferon gamma in the lungs of Mycoplasma pulmonis-infected mice. Microbiol Immunol 1994; 38: $345-352$.

108. Razin S, Jacobs E. Review article: mycoplasma adhesion. J Gen Microbiol 1992; 138: 407-422.

109. Roberts DD, Olson LD, Barile MF, Ginsburg V, Krivan HC. Sialic acid-dependent adhesion of Mycoplasma pneumoniae to purified glycoproteins. J Biol Chem 1989; 264: 9289-9293.

110. Krivan HC, Olson LD, Barile MF, Ginsburg V, Roberts DD. Adhesion of Mycoplasma pneumoniae to sulfated glycolipids and inhibition by dextran sulphate. $J$ Biol Chem 1989; 264: 9283-9288.

111. Bar-Shavit Z, Goldman R, Ofek I, Sharon N, Mirelman D. Mannose-binding activity of Escherichia coli: a determinant in the attachment and ingestion of the bacteria by macrophages. Infect Immun 1980; 29: 417-424.

112. Leijh PCJ, Van Furth R, Van Zwet TL. In vitro determination of phagocytosis and intracellular killing by polymorphonuclear and mononuclear phagocytes. In: Weir DM (ed) Handbook of experimental immunology. Vol 2. Cellular immunology. Oxford, Blackwell Scientific Publications. 1986: 46.1-46.21.

113. Griffin FM, Griffin JA, Leider JE, Silverstein SC. Studies on the mechanism of phagocytosis. I. Requirements of circumferential attachment of particle-bound ligands to specific receptors on the macrophage plasma membrane. $J$ Exp Med 1975; 142: 1263-1282.

114. Rosenbusch RF, Minion FC. Cell envelope: morphology and biochemistry. In: Maniloff J (ed) Mycoplasmas: molecular biology and pathogenesis. Washington, American Society for Microbiology. 1992: 73-77.

115. Almeida RA, Wannemuehler MJ, Rosenbusch RF. Interaction of Mycoplasma dispar with bovine alveolar macrophages. Infect Immun 1992; 60: 2914-2929.

116. Almeida RA, Rosenbusch RF. Capsule like surface material of Mycoplasma dispar induced by in vitro growth in culture with bovine cells is antigenically related to similar structures expressed in vivo. Infect Immun 1991; 59: 3119-3125.

117. Howard CJ. Variation in susceptibility of bovine mycoplasmas to killing by the alternative complement pathway in bovine serum. Immunology 1980; 41: 561-568.

118. Bredt W, Bitter-Suermann D. Interaction between Mycoplasma pneumoniae and Guinea Pig complement. Infect Immun 1975; 11 : 497-504.

119. Barker LF, Patt JK. Role of complement in immune inactivation of Mycoplasma gallisepticum. J Bacteriol 1967; 94: 403-408.

120. Fernald GW, Clyde WA, Denny FW. Factors influencing growth inhibition of Mycoplasma pneumoniae by immune sera. Proc Soc Exp Biol Med 1967; 126: 161-166.

121. Bredt W. A microscopic test for rapid detection of antibodies against Mycoplasma pneumoniae. Experientia 1969; 25 : 436-437.

122. Sethi KK, Teschner M. A study on the role of complement in the immune inhibition of mycoplasmal growth. Zentralbl Immunitaetsforsch $1969 ; 138: 458-474$.

123. Gale JL, Kenny GE. Complement dependent killing of Mycoplasma pneumoniae by antibody: kinetics of the reaction. J Immunol 1970; 104: 1175-1183.

124. Tachibana DK, Hayflick L, Rosenburg LT. Effect of complete and genetically defective mouse complement on Mycoplasma canis. J Infect Dis 1970; 121: 541-544.

125. Brunner HS, Razin S, Kalica AR, Chanock RM. Lysis and death of Mycoplasma pneumoniae by antibody and complement. J Immunol 1971; 106: 907-916.

126. Brunner HS, James WD, Horswood RL, Chanock RM. Measurement of Mycoplasma pneumoniae mycoplasmacidal antibody in human serum. J Immunol 1972 109: $1491-1498$.

127. Brunner H, Kalica AR, James WD, Horswood RL, Chanock RM. Ultrastructural lesions in Mycoplasma pneumoniae membranes produced by antibody and complement. Infect Immun 1973; 7: 259-264.

128. Bredt W, Wellek B, Brunner H, Loos M. Interactions between 
Mycoplasma pneumoniae and the first component of complement. Infect Immun 1977; 15: 7-12.

129. Watanabe T. Proteolytic activity of Mycoplasma salivarium and Mycoplasma orale. Med Microbiol Immunol 1975; 161: $127-132$.

130. De Silva NS, Quinn PA. Endogenous activity of phospholipases $\mathrm{A}$ and $\mathrm{C}$ in Ureaplasma urealyticum. J Clin Microbiol 1986; 23: 354-359.

131. Bhandari S, Asnani PJ. Characterization of phospholipase $\mathrm{A}_{2}$ of Mycoplasma species. Folia Microbiol (Pratia) 1989; 34: 294-301.

132. Chappell JB, Henderson LM. The activation of the electrogenic NADPH oxidase. Biochem Soc Trans 1991; 19: $67-70$.

133. Roos D. Molecular events during phagocyte stimulation. Scand J Rheumatol 1981; Suppl 40: 46-52.

134. Arai S, Munakata T, Kuwano K. Mycoplasma interaction with lymphocytes and phagocytes: role of hydrogen peroxide released from $M$. pneumoniae. Yale J Biol Med 1983; 56: 631-638.

135. Almagor M, Kahane I, Yatziv S. Role of superoxide anion in host cell injury induced by Mycoplasma pneumoniae infection. A study in normal and trisomy 21 cells. $J$ Clin Invest $1984 ; 73$ : 842-847.

136. Kahane I. In vitro studies on the mechanism of adherence and pathogenicity of mycoplasmas. Isr J Med Sci 1984; 20 : 874-877.

137. Meier B, Habermehl GG. Evidence for superoxide dismutase and catalase in mollicutes and release of reactive oxygen species. Arch Biochem Biophys 1990; 277: 74-79.

138. Meier B, Habermehl, GG. Evidence for superoxide dismutase and catalase in mollicutes and release of reactive oxygen species. Free Rad Res Commun 1991; 12: 451-454.

139. Almagor M, Kahane I, Gilon C, Yatziv S. Protective effects of the glutathione redox cycle and vitamin $\mathrm{E}$ on cultured fibroblasts infected by Mycoplasma pneumoniae. Infect Immun 1986; 52: 240-244

140. Bilzer M, Lauterberg BH. Glutathione metabolism in activated human neutrophils: stimulation of glutathione synthesis and consumption of glutathione by reactive oxygen species. Eur J Clin Invest 1991; 21: 316-322.

141. Paoletti F, Mocali A, Aldinucci D. Superoxide-driven NAD(P)H oxidation induced by EDTA-manganese complex and mercaptoethanol. Chem-Biol Interact 1990; 76: 3-18.

142. Lo SC, Shih JW, Yang NY, Ou CY, Wang RY. A novel viruslike infectious agent in patients with AIDS. Am $J$ Trop Hyg Med 1989; 40: 213-226.

143. Falkow S. Bacterial entry into eukaryotic cells: minireview. Cell 1991; 65: 1099-1102.

144. Low IE, Eaton MD, Proctor P. Relation of catalase to substrate utilization by Mycoplasma pneumoniae. $J$ Bacteriol 1968; 95: 1425-1430.

145. Wadher BJ, Henderson CL, Miles RJ, Varasani H. A mutant of Mycoplasma mycoides subsp. mycoides lacking the $\mathrm{H}_{2} \mathrm{O}_{2}$ producing enzyme $\mathrm{L}$ - $\alpha$-glycerophosphate oxidase. FEMS Microbiol Lett 1990; 72: 127-130.

146. Lynch RE, Cole BC. Mycoplasma pneumoniae: a prokaryote which consumes oxygen and generates superoxide but which lacks superoxide dismutase. Biochem Biophy's Res Commun 1980; 96: 98-105.

147. Stevens P, Young LS. Quantitative granulocyte chemiluminescence in the rapid detection of impaired opsonization of Escherichia coli. Infect Immun 1977; 16: 796-804.

148. Dajani AS, Ayoub EM. Mycoplasmacidal effect of polymorphonuclear leukocyte extract. J Immunol 1969; 102: $698-702$

149. Low IE, Jacobs AA, Sbarra AJ. Mycoplasmacidal activity of a leukocyte myeloperoxidase-hydrogen peroxide-halide system. J Infect Dis 1973; 127 Suppl: S72-S76.

150. Niederman R, Brunkhorst B, Smith S, Weinreb RN, Ryder MI. Ammonia as a potential mediator of adult human peridontal infection: inhibition of neutrophil function. Arch Oral Biol 1990; 35 Suppl: S205-S209.

151. Brunkhorst B, Niederman R. Ammonium decreases human polymorphonuclear leukocyte cytoskeleton actin. Infect Immun 1991; 59: 1378-1386.

152. Stalheim OHV, Gallagher JE. Ureaplasmal epithelial lesions related to ammonia. Infect Immun 1977; 15: 995-996.

153. Matsuura M, Seto $\mathrm{K}$, Watanabe T. Ammonia production as a virulence expression by Mycoplasma salivarium. Microbiol Immunol 1990; 34: 467-490.

154. Marletta MA, Yoon PS, Iyenger R, Leaf CD, Wishonok JS. Macrophage oxidation of $\mathrm{L}$-arginine to nitrite and nitrate: nitric oxide is an intermediate. Biochemistry 1988; 27 : 8706-8711

155. Keller R, Geiges M, Keist R. L-Arginine dependent reactive nitrogen intermediates as mediators of tumor cell killing by activated macrophages. Cancer Res 1990; 50: $1421-1425$.

156. Nathan CF, Hibbs JB. Role of nitric oxide synthesis in macrophage antimicrobial activity. Curr Opin Immunol 1991; 3: 65-70.

157. Follin $\mathrm{P}$, Dahlgren $\mathrm{C}$. Altered $\mathrm{O}_{2}^{-} / \mathrm{H}_{2} \mathrm{O}_{2}$ production ratio by in vitro and in vivo primed human neutrophils. Biochem Biophys Res Commun 1990; 167: 970-976.

158. Stuart PM. Mycoplasmal induction of cytokine production and major histocompatibility complex expression. Clin Infect Dis 1993; 17 Suppl S1: S187-S191.

159. Loos M, Brunner $\mathrm{H}$. Complement components $(\mathrm{Cl}, \mathrm{C} 2, \mathrm{C} 3$. C4) in bronchial secretions after intranasal infection of Guinea Pigs with Mycoplasma pneumoniae: dissociation of unspecific and specific defense mechanisms. Infect Immun 1979; 25: 583-585.

160. Egwang TG, Befus AD. The role of complement in the induction and regulation of immune responses. Immunology 1984; 51: 207-224.

161. Ezekowitz RAB, Sim RB, MacPherson GG, Gordon S. Interaction of human monocytes, macrophages, and polymorphonuclear leukocytes with zymosan in vitro. Role of type 3 complement receptors and macrophagederived complement. J Clin Invest 1985; 76 : 2368-2376.

162. Gelfand EW. Unique susceptibility of patients with antibody deficiency to mycoplasma infection. Clin Infect Dis 1993. 17 Suppl S1 : 250-253.

163. Slater TF. Free-radical mechanisms in tissue injury. Biochem $J$ $1984 ; 222: 1-15$. 